Research, part of a Special Feature on Beyond Carbon: Enabling Justice and Equity in REDD+ Across Levels of Governance

\title{
Equity and REDD+ in the Media: a Comparative Analysis of Policy Discourses
}

\author{
Monica Di Gregorio ${ }^{1}$, Maria Brockhaus $^{2}$, Tim Cronin $^{3}$, Efrian Muharrom $^{2}$, Levania Santoso $^{2}$, Sofi Mardiah $^{2}$ and Mirjam $^{\text {Bir }}$ \\ Büdenbender $^{4}$
}

ABSTRACT. Reducing emissions from deforestation and forest degradation (REDD+) is primarily a market-based mechanism for achieving the effective reduction of carbon emissions from forests. Increasingly, however, concerns are being raised about the implications of REDD+ for equity, including the importance of equity for achieving effective carbon emission reductions from forests. Equity is a multifaceted concept that is understood differently by different actors and at different scales, and public discourse helps determine which equity concerns reach the national policy agenda. Results from a comparative media analysis of REDD+ public discourse in four countries show that policy makers focus more on international than national equity concerns, and that they neglect both the need for increased participation in decision making and recognition of local and indigenous rights. To move from addressing the symptoms to addressing the causes of inequality in REDD+, policy actors need to address issues related to contextual equity, that is, the social and political root causes of inequality.

Key Words: comparative analysis; discourse; equity; media analysis; mitigation; REDD+

\section{INTRODUCTION}

Reducing emissions from deforestation and forest degradation (REDD+) is presented at the global level as an effective and cost-efficient option for mitigating climate change (Stern 2007). Because REDD+ is a market mechanism aimed at achieving carbon sequestration from forests at the lowest possible cost, equity outcomes are not an integral part of its design. However, the extent to which national REDD+ strategies and policies will be able to deliver equitable outcomes is increasingly being debated (Peskett et al. 2011).

The reality that REDD+ is likely to produce both winners and losers is reflected in the growing concerns expressed in international climate change negotiations and in the literature. In particular, equitable distribution of benefits has been identified as a key challenge in REDD+ implementation (Ghazoul et al. 2010). Other concerns range from issues of global equity, such as the demand by developing countries that developed countries help finance forest mitigation because of their historical responsibility for carbon emissions, to local equity outcomes linked to the impacts of REDD+ projects on livelihoods, tenure, and carbon rights, and the need to ensure local participation in decision-making processes (Brown et al. 2008, Cotula and Mayers 2009, Okereke and Dooley 2010, Larson 2011). The inclusion of safeguards in the Cancun Agreements under the United Nations Framework Convention on Climate Change (UNFCCC) demonstrates that equity, in terms of both distribution of costs and benefits and equal participation in decision making, is essential for ensuring both the legitimacy and the effectiveness of REDD+ (Chhatre et al. 2012, McDermott et al. 2012a).
However, equity is understood, interpreted, and justified in different ways by different actors at different scales (Sen 2009). Policy actors use discursive practices, which are the processes by which cultural meanings are produced and understood (Duranti 2001), to encourage specific understandings of equity while marginalizing others (Luttrell et al. 2012). Consequently, equity remains a contentious issue in this policy domain. Our aim, therefore, is not to provide a normative answer about what equitable outcomes should look like, but to investigate which discourses around equity and REDD+ dominate national public debates, and which are more likely to address the root causes of inequality in national contexts.

As national REDD+ strategies take shape, in some countries equity concerns are prevalent in public debates and resonate in the media. In other countries, policy discourse engages less with such concerns. Although members of the media are policy actors in their own right, state and nonstate actors use the media to publicize their own claims and to influence policy decisions (Koopmans and Statham 1999a, Boykoff 2009). Investigating media representations of such claims helps to assess how policy actors' opinions about equity are presented in the public domain and which REDD+ policy choices are open for public debate and which are marginalized.

We present a comparative analysis of how equity is framed in media representations of national REDD+ policy debates in four countries: Indonesia, Brazil, Vietnam, and Peru. Our aims are to assess the diversity of national public debates on equity and REDD+ and to answer the following research questions: 
(1) How do distinct policy actors frame equity issues and justifications for action in REDD+ policy debates in the national media? How does this define and limit policy choices? (2) How do dominant discourses on equity enable or hinder policy action to tackle the root causes of inequality associated with REDD+ developments?

The analysis focuses on two aspects of how policy actors frame equity in the media: their understanding of equity, which we label "equity issues," and the arguments they use to justify calls for increased equity, "equity justifications." To our knowledge, no media analysis on REDD+ has focused expressly on equity debates, although a number of studies have been undertaken using media analysis to investigate public debates around REDD+ (Cronin and Santoso 2010, Pham 2010, May et al. 2011, Perla Alvarez et al. 2012), as part of the project supporting this research.

We provide background information on discourse in the media and in science and policy on REDD+ and present a theoretical framework for the analysis of equity in media discourse, which we use to assess how policy actors frame equity in REDD+ debates in the media. We conduct a comparative media analysis in the four countries. The analysis identifies the key equity issues and justifications of different policy actors and assesses the extent to which these target the root causes of inequality. Finally, we draw implications about the opportunities to position equity concerns on national REDD+ policy agendas.

\section{BACKGROUND}

\section{Discourse, media, and REDD+}

Discourse is part of the institutional architecture that structures the behavior of actors and enables and constrains policy action (Hajer 1995). It can be defined as "a specific ensemble of ideas, concepts, and categorizations that are produced, reproduced, and transformed in a particular set of practices and through which meaning is given to physical and social realities" (Hajer 1995:44). The way in which different policy actors frame equity debates and the justifications that they use to support calls for equity shape the very understanding of equity in the REDD+ arena.

By selecting news and highlighting specific views about REDD+, journalists and editors influence which REDD+ equity issues are discussed in the public domain and how. Journalistic norms, ideological positions, power structures in the media, and the broader political context all affect how the media frames these issues (Trumbo 1996, Carvalho and Burgess 2005, Carvalho 2007, Boykoff 2008). Framing here is defined as "the ways in which elements of discourse are assembled that then privilege certain interpretations and understandings over others" (Boykoff 2008:555). However, media coverage of environmental issues draws also on interviews with state and nonstate actors such as scientists, environmental organizations, and the private sector (Boykoff 2009). Thus, the media are both "agents of reproduction of culture" and "the site of symbolic contest over meaning" (Hammond 2004:66), driving policy discourse and filtering the opinions of other policy actors (Andsager 2000, Boykoff 2008).

We focus on how the media reports the opinions about equity and REDD+ held by various policy actors, predominantly nonmedia actors. This approach is quite distinct from most media analyses on climate change, which tend to focus exclusively on the role of the media in framing debates (Trumbo 1996, Carvalho 2007, Boykoff 2008), although it has been used in other studies (Koopsman and Statham 1999b). Of course, although the media selects and reframes the opinions of other policy actors, it does have a responsibility for accuracy when reporting opinions of third parties to maintain their reputation, especially when statements are made by a named source (McCarthy et al. 1996).

In the case of REDD+, journalists have to deal with a new and at times highly technical topic. A number of the media-based discourse analyses in REDD+ countries undertaken for this study show that these technical challenges contribute to the limited reporting on REDD+, the small numbers of opinion pieces and editorials, and high reliance on input from nonmedia actors (Pham 2010, May et al. 2011, Babon et al. 2012, Perla Alvarez et al. 2012). In fact, a number of international and national organizations, such as UN-REDD, The Center for People and Forests (RECOFTC), International Union for Conservation of Nature (IUCN), The REDD Desk, and the Indonesian REDD+ Task Force, have been producing guides, engaging in training, and seeking other capacitybuilding opportunities to strengthen the ability of journalists in REDD+ countries to engage with the issue (Migo 2012, UN-REDD 2012).

\section{Equity and REDD+ in policy and science discourse}

Under the Cancun Agreements of the UNFCCC, equity concerns must be included in the design of REDD+ safeguards, following the guidelines contained in Appendix I to Decision 1/CP.16, guidelines that nations must take into account when operationalizing REDD+ (UNFCCC 2010). First, the guidelines mention the need to respect sovereignty in the development and implementation of national REDD+ and forest governance, thus emphasizing that all countries have equal rights (Heyward 2007). Second, the guidelines stress the need to "enhance other social and environmental benefits" (UNFCCC 2010:27), including poverty reduction, thus reflecting concerns about how benefits and costs might be distributed. The requirement to ensure "respect for knowledge and rights of indigenous peoples and members of local communities" (UNFCCC 2010:26) raises questions about the initial distribution of resources and how it will affect equity, and whether REDD+ will result in equity-enhancing outcomes 
(McDermott et al. 2012b). Finally, the need to ensure "full and effective participation of relevant stakeholders, in particular indigenous peoples and local communities" (UNFCCC 2010:26) reflects concerns with procedural justice, namely, who is included in decision making.

Similarly, a growing literature has been exploring equity concerns related to REDD+. In particular, the inadequate recognition of local people's rights to carbon, trees, and land has been criticized as creating an unequal playing field, which will ultimately affect the distribution of and access to benefits (Sunderlin et al. 2009, Larson 2011, Sikor and Stahl 2011, Chhatre et al. 2012). As REDD+ increases the value of forests, the drive for governments to recentralize forest control will intensify and "green" land grabs might lead to dispossession (Cotula and Mayers 2009, Phelps et al. 2010, Fairhead et al. 2012, World Bank 2010 as cited in Mustalahti et al. 2012). Facilitating shifts in control from local to global actors are narratives that portray local users as "forest destroyers" (Forsyth and Walker 2008, Beymer-Farris and Bassett 2012). Such aspects potentially have negative consequences for local livelihoods and are likely to exacerbate existing inequalities. Even where adequate rules and procedures are in place, implementation is hampered by structural constraints such as the weak agency of local people. In these cases, even a "noharm approach" to REDD+ is unlikely to prevent adverse livelihood impacts (Brown et al. 2008, Mustalahti et al. 2012).

Evidence of the failure to include forest-dependent communities in policy decisions casts doubt on the ability of REDD+ to ensure procedural equity, that is, equitable participation and representation in decision-making processes (Griffiths 2007, Cotula and Mayers 2009). Also of concern is that REDD+ might actually discriminate against local communities that are already making demonstrable efforts to conserve forest resources (Kanninen et al. 2007). Thus, when implementing any REDD+ scheme, benefit-sharing rules must be defined, an issue that is already at the center of national policy discourse (Rawls and Kelly 2001, Streck 2009). Finally, another concern is gender equity, which is related to the spheres of both distributive and procedural justice (Terry 2009). The evidence thus suggests that, at the very best, market-based REDD+ schemes might leave existing procedural and distributive equity conditions untouched, and, at worst, might exacerbate existing inequalities, a concern already raised in the broader literature on payments for environmental services (Corbera et al. 2007, Corbera 2012).

\section{THEORETICAL FRAMEWORK: FRAMING DISCOURSE ON EQUITY AND REDD+}

The framework we used to assess the discourse of diverse policy actors on equity and REDD+, presented below, highlights the multifaceted and contentious nature of equity in terms of both issues of focus and justifications for action.
Using the framework, we can categorize discourses on equity and REDD+ according to whether they challenge existing institutional structures.

\section{Dimensions of equity}

We adopt a framework that distinguishes between three dimensions of equity: distributive, procedural, and contextual equity (McDermott et al. 2012b; Table 1). Here, distributive justice refers to how benefits and costs are allocated in society (Fraser 2009). Debates on benefit-sharing arrangements are an example of a discourse on equity and REDD+ that focuses on distributive justice. However, equity outcomes also depend on who can participate in making such decisions. This aspect is then related to the second dimension, procedural justice, which concerns participation, recognition, and representation (Anand 2001). Support for procedural justice is seen, for example, in calls for increased participation in REDD+ decision-making processes, including procedural requirements such as free, prior, and informed consent (Brown et al. 2008). Procedural justice is usually interpreted as equal access to democratic decision making and is therefore a key component of the legitimacy of REDD+ policy deliberations (Young 1990, Adger et al. 2006). Whereas distributive and procedural equity investigate outcomes and processes, the third fundamental dimension, contextual equity, refers to inequalities embedded in preexisting social and political conditions. This dimension recognizes that equity is a "situated phenomenon" (Walzer 1983 as cited in McDermott et al. 2012b:4), in that it considers the institutional, socioeconomic, and political conditions that determine unequal opportunities in participation and distributive outcomes (McDermott et al. 2012b).

We argue that, as we move from discourses that draw attention to distributive equity, to procedural and then to contextual equity, policy actors' strategies increasingly challenge the status quo. They shift from accepting inequalities embedded in existing institutional and social structures to directly challenging the root causes of inequality. We refer to strategies that accept or work within the boundaries of contextual equity conditions as "affirmative strategies" and those that challenge them "transformative strategies" (Fraser and Honneth 2003).

\section{Social justice principles and justifications for equity}

The second aspect of the framework refers to the normative principles of social justice that underlie discourses on equity. Policy actors rely on different principles of justice to justify calls for equity, which explains the multifaceted and contentious nature of equity, because different principles are likely to lead to different policy solutions (Sen 2009). We categorize the justifications for equity according to four principles of social justice: needs, rights, interests, and merit (Miller 1999). To these we add a fifth principle that we call "fairness," which was derived inductively from the data. 
Table 1. Equity framework for REDD+ media discourse (Adapted from McDermott et al. 2012b). Labels in parentheses used in figures.

\begin{tabular}{|c|c|c|c|}
\hline Dimension of equity discourse & Distributive equity & Procedural equity & Contextual equity \\
\hline \multirow[t]{3}{*}{$\begin{array}{l}\text { Examples of equity issues } \\
\text { linked to each dimensions }\end{array}$} & $\begin{array}{l}\text { Mechanisms allocating costs and } \\
\text { benefits of REDD+ (Benefit-sharing) }\end{array}$ & $\begin{array}{l}\text { National sovereignty over } \\
\text { development and implementation of } \\
\text { national REDD+ policy decisions } \\
\text { (Sovereignty) }\end{array}$ & $\begin{array}{l}\text { Recognition of local rights to carbon, } \\
\text { forest, and trees (Tenure and } \\
\text { indigenous rights) }\end{array}$ \\
\hline & $\begin{array}{l}\text { Enhancing social and environmental } \\
\text { benefits (Livelihoods) }\end{array}$ & $\begin{array}{l}\text { Nature and access to participation for } \\
\text { relevant stakeholders (Participation) }\end{array}$ & $\begin{array}{l}\text { Equal rights for man and women } \\
\text { (Gender) }\end{array}$ \\
\hline & $\begin{array}{l}\text { Equal access to benefits for man and } \\
\text { women (Gender) }\end{array}$ & $\begin{array}{l}\text { Equal participation of man and women } \\
\text { (Gender) }\end{array}$ & \\
\hline \multirow[t]{2}{*}{$\begin{array}{l}\text { Examples of normative } \\
\text { questions }\end{array}$} & $\begin{array}{l}\text { How should benefits and costs of } \\
\text { REDD+ activities be distributed? }\end{array}$ & $\begin{array}{l}\text { Who should participate in REDD+ } \\
\text { decision making? }\end{array}$ & $\begin{array}{l}\text { How do existing property rights } \\
\text { arrangements impact equity outcomes } \\
\text { in REDD+? }\end{array}$ \\
\hline & $\begin{array}{l}\text { Who should contribute to fund REDD+ } \\
\text { development and implementation? }\end{array}$ & & $\begin{array}{l}\text { Which socioeconomic and political } \\
\text { factors determine inequality in existing } \\
\text { institutional arrangements? }\end{array}$ \\
\hline Type of strategies & Affirmative strategies & $\leftrightarrow$ & Transformational strategies \\
\hline \multirow{5}{*}{$\begin{array}{l}\text { Underlying principles of } \\
\text { justice (type of justifications) }\end{array}$} & Interest-based & Interest-based & Interest-based \\
\hline & Needs-based & Needs-based & Needs-based \\
\hline & Rights-based & Rights-based & Rights-based \\
\hline & Merit-based & Merit-based & Merit-based \\
\hline & Fairness-based & Fairness-based & Fairness-based \\
\hline
\end{tabular}

1. Needs-based justifications stress that distribution of benefits should take into account the needs of marginalized, vulnerable social groups and particularly emphasize pro-poor policies. Such justifications are often combined with arguments suggesting that the delivery of benefits to the poor will enhance the sustainability, acceptance, and legitimacy of REDD+ schemes (Peskett et al. 2008). This kind of approach encompasses both moral and ethical justifications and helps integrate mitigation of climate change with poverty-reduction goals.

2. Rights-based justifications argue that REDD+ compensation should reflect rights and entitlements. In the REDD+ domain, achieving this often requires determining, first, who owns the carbon and then, more broadly, who has rights to access, manage, and control forest resources (Cotula and Mayers 2009, Sunderlin et al. 2009, Doherty and Schroeder 2011). The aim of calls for informal and customary rights to be recognized is to reposition a (perceived) 'unequal playing field' and address contextual equity (Larson and Ribot 2007, Sikor and Stahl 2011).

3. Interests-based justifications refer to the principle that all interested or affected stakeholders should be involved in REDD+ decision-making processes (Sikor and Stahl 2011), namely in participation, recognition, and representation (Anand 2001, Fraser 2009). Inclusion of all relevant stakeholders in REDD+ decision making is challenging as the barriers to the effective use of free, prior, and informed consent processes demonstrate (Griffiths 2007).

4. Merit-based (or stewardship) justifications argue that compensation should reward those who have demonstrated the ability to preserve and manage forests sustainably. Although rewarding long-term stewardship has been discussed at length in relation to equity and REDD+, it seems to be neglected in practice (M. Richards, unpublished manuscript). One concern with rewarding preexisting stewardship is that it may not guarantee the additionality of emission reductions (Angelsen 2008).

5. Fairness-based justifications emphasize equal freedom and opportunities for and equal treatment of all actors, but are open to interpretation (Tyler and Belliveau 1995). They are less specific than justifications based on rights, needs, interests, and stewardship. An example is a reference to historical responsibility as a justification for demanding that developed countries reduce carbon emissions. Fairness not only refers to current actors, but can be extended to include future generations (Weiss 1990).

Some claims for pursuing equity propose clear actions, whereas others do not. For example, many of the general calls for increased "fairness" do not suggest any specific policy 
solution; they merely highlight a general perception that someone has been treated unjustly. Although such perceptions can help gather support for a challenge to existing arrangements, they do not contribute toward actual solutions. By contrast, when justifications are coupled with specific proposals for addressing equity problems, claims can more specifically inform REDD+ policy. They can help resolve problems and focus attention on targeted solutions for demanding action by policy makers (Forsyth 2003, Sikor and Stahl 2011).

\section{METHODS}

In contrast to other media analyses on climate change (e.g., Boykoff 2008), we investigate predominantly public statements by nonmedia actors reported in the media (Hammond 2008, Koopsman and Statham 1999a,b). We analyze these statements to assess how different policy actors understand equity issues and how they justify actions for increased equity in the public sphere.

Media frames are defined as "patterns of cognition, interpretation, and presentation, of selection, emphasis, and exclusion, by which symbol-handlers routinely organize discourse" (Gitlin 1980:7). These frames can include quotes and reported statements of policy actors as well as opinions of journalists. We call such opinion statements "stances" or the "orientation[s] to states of affairs" (Kockleman 2004:127).

The analysis is based on coverage of three major national newspapers in each country, from December 2005, which coincided with the 11th UNFCCC Conference of the Parties when REDD+ entered the international climate change negotiations, to December 2010. The four countries selected are all actively involved in REDD+ policy design and implementation, but are at different stages. Indonesia and Brazil possess among the vastest areas of remaining tropical forest and their policy processes and activities on REDD+ are quite advanced, e.g., Indonesia submitted its Readiness Preparation Proposal (R-PP) to the World Bank's Forest Carbon Partnership Facility in 2009. Peru and Vietnam have smaller forest areas and the former is at an earlier stage in REDD+ development, e.g., Peru submitted its R-PP in 2011 (Di Gregorio et al. 2012a).

Newspapers were selected based on two criteria: high national circulation and representation of a broad political spectrum. A keyword search for "REDD," "reducing emissions from deforestation and forest degradation," and related terms was used to identify articles that discussed REDD+. Restricting the analysis to print newspapers is somewhat limiting, but it facilitates consistent coding and cross-country comparisons, particularly in relation to the level of coverage.

A standardized code book was used to ensure consistency of coding and comparability across countries (Di Gregorio et al. 2012b). The code book set out three levels of coding. The first identified descriptive variables of the articles such as source, type of article, date, length, and author. The second level identified the media frames and certain characteristics of the frames, such as their main theme and scale, i.e., global, national, and local. The third level of coding identified the frames in more detail, including the stances of up to two of the most prominent policy actors mentioned in the frames. This included coding the name of the actor and the organization with which he/she was affiliated, noting the opinion statement (stance) attributed to the actor and whether or not the stance referred to equity. Policy actors included any organization or individual expressing a stance in the frames. They were grouped into 10 categories: national-level state actors, subnational state actors, domestic civil society, international civil society (primarily NGOs), businesses, national research institutes, international research institutes, intergovernmental organizations, journalists, and other individuals. Although the media filters which stances appear, we identify journalists as stance holders only in editorials and opinion pieces; all other stances were attributed by the journalists to specific nonmedia actors. Each equity-related stance was then analyzed through open coding and classified according to (a) type of equity issue and (b) principle of social justice used, explicitly or implicitly, to support the stance. Six equity issues were identified: benefit-sharing, tenure and indigenous rights, livelihoods and poverty, participation, sovereignty, and gender equity. The examples of equity issues in Table 1 are drawn from these categories. The open coding process employed both inductive and deductive approaches; the coder was provided with a preliminary list of equity issues and principles of social justice derived from the literature, but could modify the list or add new categories for both equity issues and justifications as they emerged from the open coding of the stances.

Comparisons across countries are complicated by the fact that in each country the influence of the media on public discourse differs, as does the influence of specific policy actors and of the broader political context. For example, in Vietnam, the state has much stronger control over the media than in Brazil, Indonesia, or Peru (Freedom House 2009). We recognize this as a limitation of the study, as is our relatively minor consideration of media selection and description bias.

\section{RESULTS}

Between 2005 and 2010, a total of 906 articles mentioning REDD+ were published in the four countries, with REDD+ a major focus of 582 of these. The remainder was considered to have mentioned REDD+ in passing only. Of the 582 articles, Indonesia and Brazil accounted for 265 and 257 articles, respectively. In Vietnam and Peru, coverage was much more limited, with only 34 and 26 articles on REDD+ published in the same period. Overall, the frequency of coverage could be said to reflect the progress of REDD+ policy processes up to 
2010, as well as the greater importance of forests in Indonesia and Brazil than in Vietnam and Peru (Di Gregorio et al. 2012a).

Just as the total number of newspaper articles on REDD+ varied significantly across countries, predictably so too did the number of stances expressed by policy actors within these articles, ranging from 20 (Peru) to 386 (Indonesia; Table 2). Between 25\% (Peru) and 61\% (Vietnam) of all stances were related to equity in some way.

Table 2. Total number of stances and number of stances on equity.

\begin{tabular}{lcccc}
\hline \hline & Indonesia & Brazil & Vietnam & Peru \\
\hline Total number of stances & 386 & 173 & 31 & 20 \\
$\begin{array}{l}\text { Number of stances on } \\
\text { equity }\end{array}$ & 124 & 55 & 19 & 5 \\
$\%$ of stances on equity & 32 & 32 & 61 & 25 \\
\hline
\end{tabular}

The following results examine the nature of these stances, including who is concerned about equity, what they are concerned about, and how they justify actions to address these concerns.

\section{Who is concerned about equity in REDD+?}

The media generally devotes more space to politics and policy making than to other themes, and we can therefore expect the opinions of state actors to be more visible in the media than those of other policy actors (Boykoff 2008). Overall, state actors were the most vocal group in Indonesia, Brazil, and Vietnam. However, in Peru, media discourse more frequently featured international civil society, research institutes, or intergovernmental organizations.

This pattern continues with the stances related to equity. As Table 3 illustrates, state actors formed the most prominent group discussing equity issues in Indonesia, Brazil, and Vietnam, accounting for between 31\% (Indonesia and Brazil) and 63\% (Vietnam) of all stances. In Peru, however, state actors were completely absent, which might reflect the relatively early stage of national REDD+ policy formulation in Peru (Perla Alvarez et al. 2012).

Furthermore, Indonesia and Brazil had the greatest range of actors discussing equity issues, as seen in Table 3. By contrast, equity-related discourse featured just three actor groups in Vietnam (national state actors, state-owned businesses, and intergovernmental organizations) and two in Peru (domestic and international civil society). Evidently, there is a correlation between high media coverage of equity in REDD+ and a high diversity of policy actors discussing these issues. Indonesia was the only country that featured journalists as policy actors in their own right, through editorials or opinion pieces on REDD+. The absence of such opinion pieces in Brazil, Vietnam, and Peru might reflect the highly technical and political nature of the topic, and therefore the extent to which journalists have tended to rely on the opinions of other actors in their coverage (Cronin and Santoso 2010, Pham 2010, May et al. 2011).

Table 3. Number of stances on equity by actor type (percentage in brackets).

\begin{tabular}{lcccc}
\hline \hline Type of actor & Indonesia & Brazil & Vietnam & Peru \\
\hline State (national) & $38(31)$ & $17(31)$ & $12(63)$ & \\
State (subnational) & $11(9)$ & $7(13)$ & & \\
Civil society (domestic) & $36(29)$ & $16(29)$ & & $2(40)$ \\
Civil society & $17(14)$ & $4(7)$ & & $2(40)$ \\
(international) & & & & \\
Business & $3(2)$ & $1(2)$ & $2(11)$ & \\
Research (domestic) & $3(2)$ & $3(5)$ & & \\
Research (international) & $5(4)$ & $2(4)$ & & \\
Intergovernmental & $6(5)$ & $4(7)$ & $5(26)$ & \\
organizations & & & & \\
Individuals & $1(1)$ & $1(2)$ & & $1(1)$ \\
Journalists & $4(3)$ & & & \\
Total no. of actors & $124(100)$ & $55(100)$ & $19(100)$ & $5(100)$ \\
\hline
\end{tabular}

In all countries except Vietnam, domestic and international civil society actors were the second most prominent group debating equity issues in the media. Interestingly, in Vietnam, the only authoritarian regime in the sample, no civil society actors at all, domestic or international, expressed an opinion on any aspect of REDD+, including equity. As seen in Figure 1, however, Vietnam had the largest proportion of stances relating to equity in REDD+.

Fig. 1. Equity issues discussed in the media (percentage and frequencies).

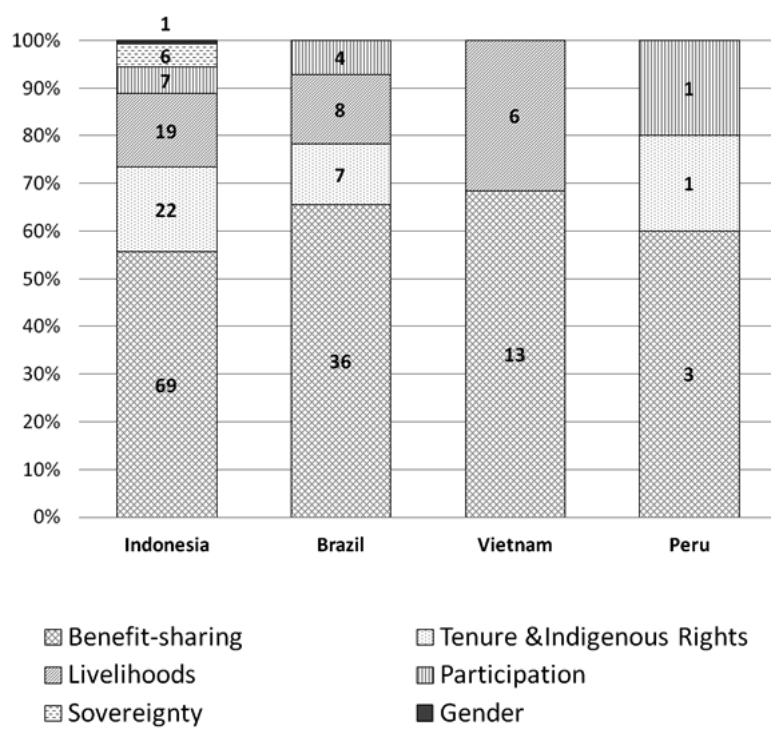


Fig. 2. Equity issues discussed by most featured actor groups by country.

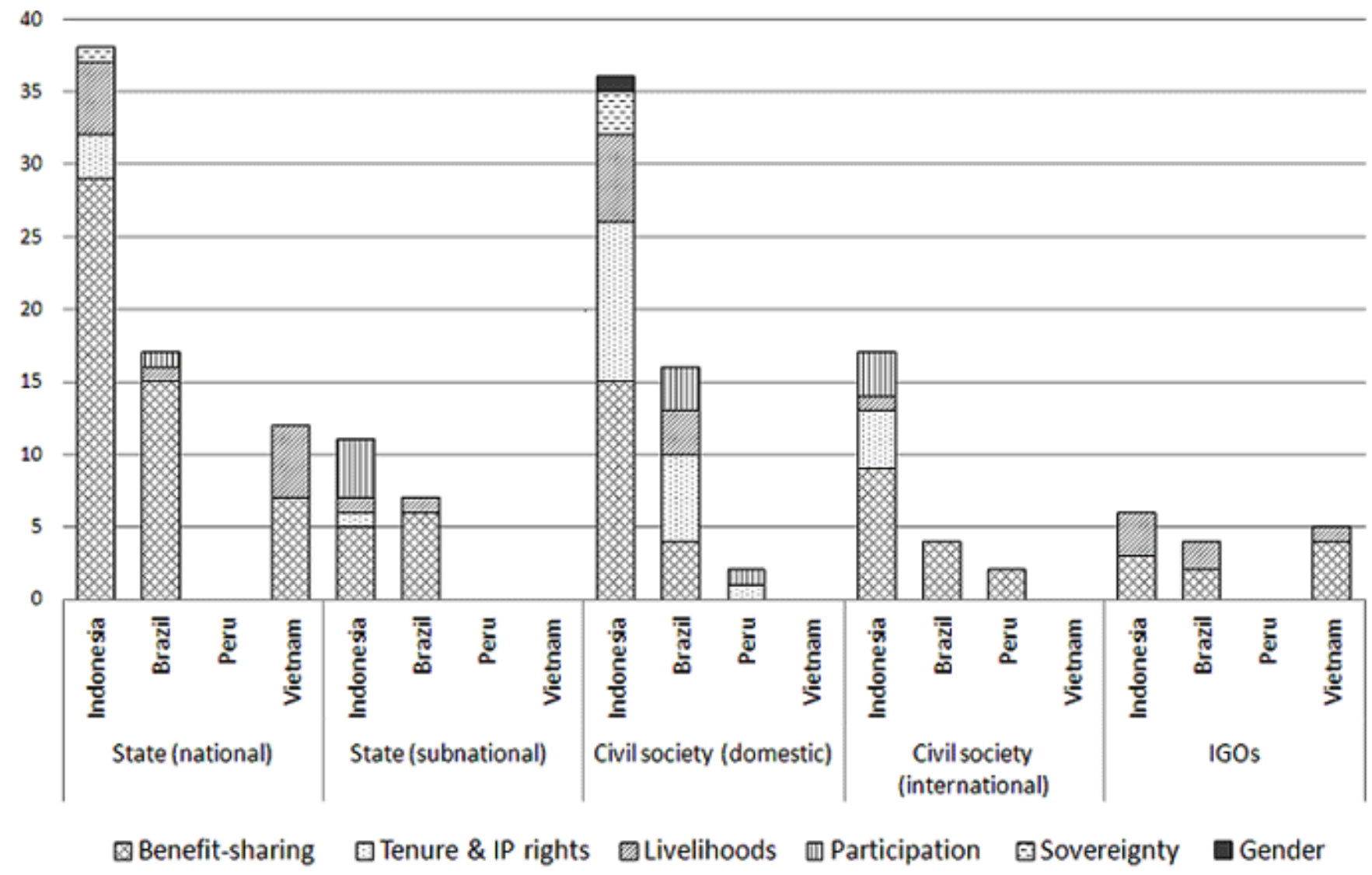

Even so, state and civil society emerge as the main policy actors seeking to define how REDD+ equity is understood and discussed in the public sphere. Yet, as we will see when we examine the nature of their stances, these actors tend to frame the notion of equity in very different ways.

\section{What are they concerned about?}

As outlined in the Methods, we used open coding to categorize the stances on REDD+ and equity, which elicited six specific equity-related issues. As seen in Figure 2, the most prominent issue across all countries by a large margin was benefit sharing, accounting for between 56\% (Indonesia) and 68\% (Vietnam) of the equity issues discussed. Furthermore, three of the four stances held by media actors are related to benefit sharing. Benefit sharing here refers to the distribution of REDD+ costs and benefits, and therefore to distributive equity. Livelihoods and tenure were also frequently discussed, whereas gender, sovereignty, and participation were not common issues.

A closer examination of the nature of the stances on benefit sharing shows that this issue is framed very differently depending on who is represented. For example, in Indonesia and Brazil state actors tend to refer primarily to developed and developing countries sharing the burden of emission reductions and REDD+ financing responsibilities, thus framing benefit sharing as a global issue. Consider the following position put forward in 2007 by Indonesia's then Minister of Forestry, M.S. Kaban:

For Kaban, as long as there is no commitment from developed countries to adopt REDD, global efforts to resolve climate change will remain unfair. "If there are no ties for developed countries, developing countries will have no certainty, because the prop for developing countries is resources," he said (Menhut Usul ... 2007).

By contrast, domestic civil society actors are more concerned with the distribution of REDD+ costs and benefits at the domestic level. For example, they might draw attention to the situation of local forest users and vulnerable communities that are likely to bear much of the cost of implementing REDD+ schemes: "The government must support the interests of the people, not corporations" (Joji Carino, Tebteba Foundation, as cited in Hartiningsih and Arif 2007). 
Whereas state actors in Indonesia and Brazil were most concerned with the sharing of REDD+ costs and benefits at the global level (79\% and $87 \%$, respectively), Vietnamese state actors framed such issues at the domestic level (86\%), and were also greatly concerned with equity in livelihood issues. Overall, in Indonesia and Brazil, 63\% and 76\% of all stances on equity expressed by state actors referred to global equity, respectively, whereas in Vietnam, $92 \%$ referred to domestic equity. In Peru, global concerns were mainly represented by international civil society.

Just as the framing of stances related to equity in benefit sharing varied according to who was speaking, so too did perspectives on equity in livelihoods. On the one hand, stances on livelihoods expressed by state actors, particularly in Vietnam, tended to address the potential for REDD+ to have positive impacts on livelihoods. For example, in October 2010, a representative from the Ministry of Agriculture and Rural Development was quoted in Vietnam's The People newspaper as saying: "REDD can provide incentives for local people to protect the forest and earn additional income" (Mai 2010). On the other hand, civil society actors often raised concerns about how REDD+ might threaten existing livelihoods: "The REDD concept is a lighthouse project that the political elite and scientists in Jakarta can enjoy by paying little attention to the interests of communities living in and around forests" (Hartono 2007).

Equity issues related to tenure arrangements and indigenous rights were primarily raised by domestic civil society actors and, in the case of Indonesia, by international NGOs and research institutes. Among these issues were calls for the recognition of local rights, thus drawing attention to a preexisting inequitable institutional context. Only in three instances did state actors in Indonesia raise issues related to monitoring green land grabs and respecting local community and indigenous rights.

The small amount of attention given to participation and procedural equity is somewhat surprising given the widespread criticism of the lack of effective participation by local forest users in the literature and in reviews of R-PPs (Griffiths 2007, Dooley et al. 2011, Williams and Davis 2012). Calls for increased participation are the domain of domestic and international civil society, and, in Indonesia, of subnational state actors, and are predominantly directed toward state actors.

\section{How do policy actors justify actions to address their equity concerns?}

The principles used to justify calls to action constitute an important aspect of the framing of equity. As described above, we coded the equity-related stances in the media according to the five social justice principles, needs, rights, interests, merit, or fairness, underlying the calls for increased equity.
As seen in Figure 3, a general call for fairness was the main argument used for increased equity in all four countries, accounting for between $40 \%$ (Peru) and 68\% (Vietnam) of all justifications for equity. For example, Ana Júlia Carepa, former Governor of Brazil's Para State, was quoted in Folha de Sau Paolo in June 2008 as saying: "The Amazon is huge and needs a solution ... It is only fair that countries pay [for its preservation]" (Países ricos ... 2008). Rights-based arguments were used predominantly in Indonesia and needs-based arguments were common in Brazil, Indonesia, and Vietnam, whereas merit-based (or stewardship) and interests-based arguments were rarely used in any countries.

Fig. 3. Justifications put forward for equity in the media (percentage and frequencies).

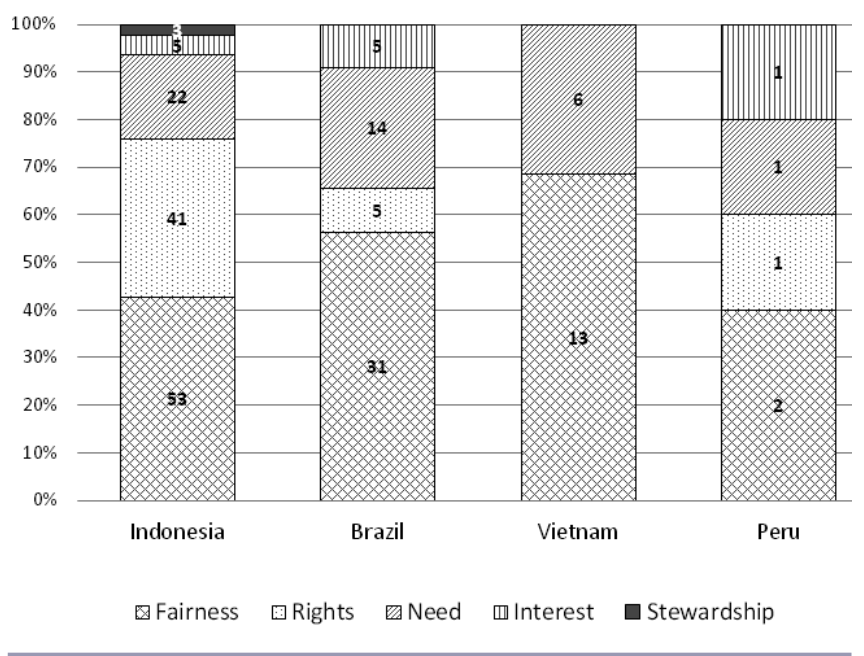

An examination of the ways in which specific actor groups justify their calls for increased equity (Fig. 4) shows that a general call for fairness was made frequently by national state actors in all countries except Peru, where no state actor took a position on equity and REDD+ in the media, and to a smaller degree by civil society actors.

Civil society actors most commonly used rights-based justifications for equity. For example, the International Forum of Indigenous Peoples on Climate Change (IFIPCC) stated that traditional communities feel that REDD+ will lead to new rights violations. In a letter to the Subsidiary Body for Scientific and Technological Advice (SBSTA) of the UNFCCC, the IFIPCC said that "REDD would violate land rights, regional boundaries and traditional communities' resources" and that they "wanted SBSTA to involve the Rights Council special reporter for basic rights and freedom for traditional communities to monitor violations that might occur in REDD implementation" (Suryandari 2007). Only in Indonesia, where domestic and international civil society used extensively rights-based justifications for increased equity, 
Fig. 4. Justifications for equity, as put forward by most featured actor groups per country.

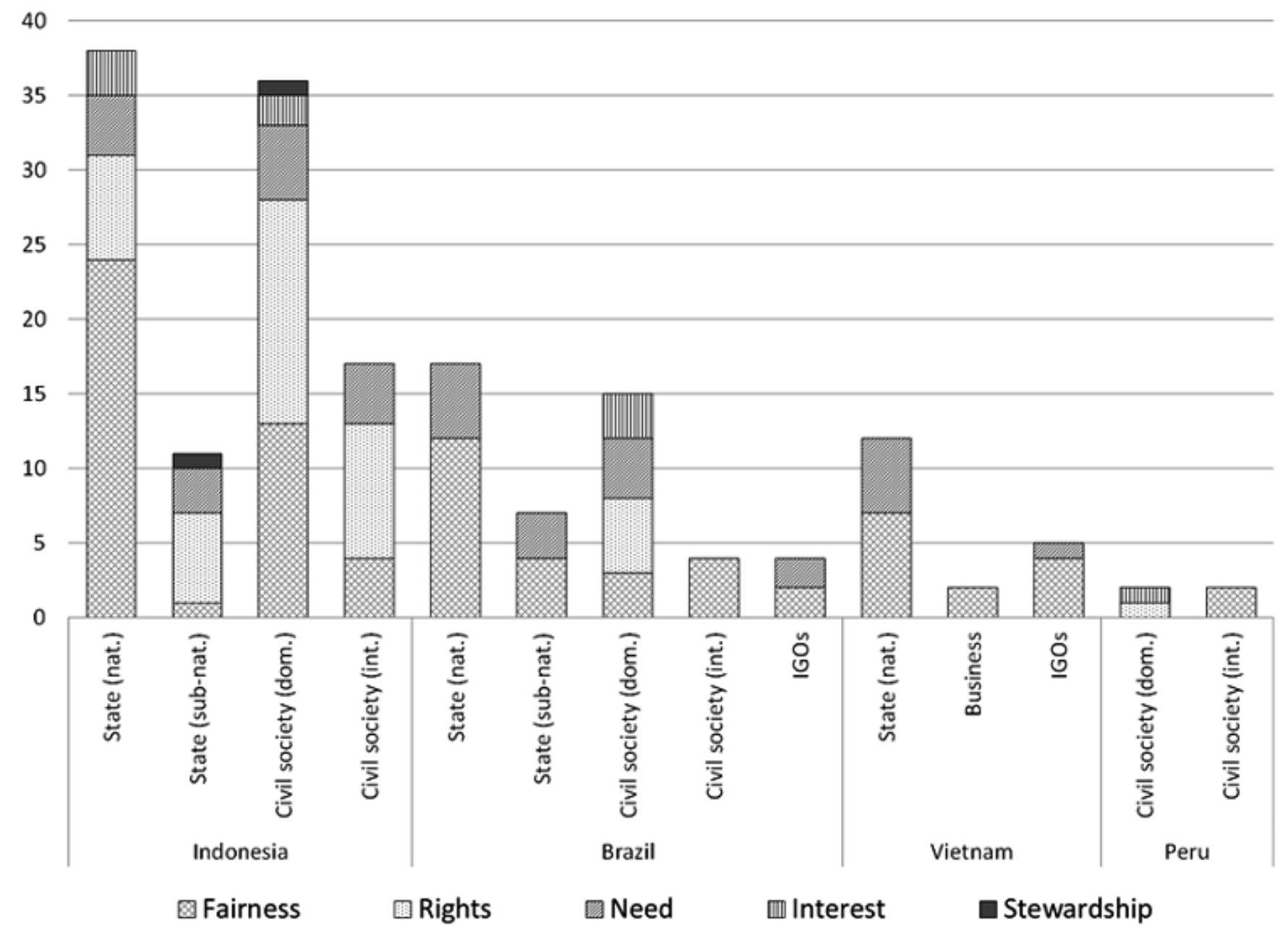

did some state actors use rights-based justifications. Such demands were more limited in Brazil and Peru and were absent in Vietnam, where civil society is not represented in media and policy debates.

The third most commonly used justification for equity is based on needs: "Forests cannot be reduced to carbon toilets. Forest functions are far more than that. Forests are the center of life for surrounding communities, and forests maintain biodiversity," (Longgena Ginting, from Friends of the Earth International, as cited in Yuwono 2007). We can see in Indonesia and Brazil that this form of justification was used by the most diverse range of state and nonstate actors, including domestic and international civil society. In Vietnam, needs-based justifications were exclusively raised by state actors, and none was used in Peru.
Evidently, as with our findings on equity-related issues, state and civil society actors tend to justify calls for equity in different ways, suggesting something of a disconnection between these two groups when it comes to policy discourse. State actors most frequently rely on calls for general fairness, and civil society on rights-based arguments.

\section{DISCUSSION}

The stronger focus on global equity issues by state actors in Indonesia and Brazil suggests that they are more concerned about their country being treated fairly in international negotiations on REDD+ than about addressing domestic equity-related REDD+ issues. In both these countries, as in Peru, the main actor group raising domestic equity issues is domestic civil society. The situation is very different in Vietnam, where state actors predominantly discuss domestic issues related to REDD+. One reason for this difference is that 
Vietnam has integrated its REDD+ activities with broader payments for environmental services schemes, which include domestic compensation schemes, rather than exclusively internationally financed ones (Pham 2010). State actors primarily take a stance in support of such schemes, with national business as the target audience. A second reason is the strict state control of the media in Vietnam, which means that the voice of nonstate actors in the media is restricted.

State actors also tend to make general calls for increased "fairness" that rarely contain any specific policy solutions; rather, such calls simply reflect a general perception that someone has been treated unjustly, which can serve only to help gather support for a challenge to existing arrangements but not to solve problems. General claims of this nature lack a strong normative justification for action and risk stalling the debate at the motivational or diagnostic level, without moving it to actionable policy proposals. By contrast, when justifications are coupled with specific proposals to address equity problems, claims can inform REDD+ policy processes more specifically. They can provide problem closure and draw attention to specific solutions as ways of demanding action by policy makers (Forsyth 2003, Sikor and Stahl 2011). This is the case with needs- and rights-based justifications for increased equity, respectively, the second and third most used justifications. Although both state and non-state actors use needs-based justifications, rights-based justifications for action are used more often by civil society actors.

The analysis also indicates that in Indonesia, Brazil, and Peru, domestic civil society is the main actor raising distributive equity concerns related to REDD+ safeguards, although state actors also engage with these issues. The primary topic of concern is benefit sharing, which dominates equity issues in all four countries, including among media actors themselves. This is not surprising, given that the definition of benefitsharing rules is a key issue of contention in REDD+ debates (Ghazoul et al. 2010, Peskett et al. 2011). Distributional issues related to livelihoods appear less frequently in the media. Nevertheless, in Brazil and Indonesia, domestic civil society is the main actor to raise these issues, followed by state actors and, to a lesser degree, intergovernmental organizations. In Vietnam, the high engagement of the state with livelihood issues is due to an explicit government goal to integrate poverty alleviation goals with REDD+; this goal was formalized through the integration of the National REDD+ Strategy with the National Forest Development Strategy and the National Forest Development and Protection Plan, which have a strong poverty alleviation focus (Pham 2010). Consequently, the government uses the media to garner support for its plans. This indicates that both the specific political context and the political ideology of the Vietnamese government are conducive to the design of a proactively antipoverty REDD+ mechanism, something not seen in the other countries. It should be noted, however, that the
Vietnamese government exclusively portrays REDD+ positively as an opportunity to improve livelihoods, whereas critical views on the possible negative livelihood impacts are absent. Indeed, in the other countries, it is predominantly civil society that denounces the possible adverse impacts. Nevertheless, that both state and nonstate actors debate livelihood issues suggests that a pro-poor equity frame provides an opening for policy debates among a variety of actors, at least in nonauthoritarian regimes. The case of Vietnam also demonstrates that, even in the absence of pressure from civil society, governments can still prioritize livelihood concerns. However, even if state actors were fully engaged in such debates, a stronger focus on livelihood impacts would be unlikely to fundamentally alter contextual inequality, because such debates leave preexisting social and political conditions and power relations, which determine the extent to which people benefit from resource distribution, largely unchanged (McDermott et al. 2012b). Hence the focus on benefit sharing and improved livelihoods most likely translates into affirmative as opposed to transformative strategies (Fraser and Honneth 2003, Corbera 2012).

Procedural equity received limited coverage in the media, and then only in Indonesia and Brazil. In both these countries, demands for increased participation again came from civil society, both domestic and international, and, in Indonesia, from subnational state actors. National state actors are not engaged. This minimal attention is concerning, given the numerous studies denouncing the lack of meaningful participation in ongoing national-level REDD+ processes (Griffiths 2007 Cotula and Mayers 2009). Achieving improvements in procedural justice is often a prerequisite for addressing distributive equity effectively in practice (Adger et al. 2006). International actors such as the Forest Carbon Partnership Facility and the UN-REDD Programme are attempting to facilitate inclusive dialogue in REDD+ national policy processes by integrating procedural requirements for participation in REDD+ readiness activities. However, changes in rules and procedures tend to have limited effectiveness in the absence of genuine buy-in by national state actors. In addition, improved participation in decision making is often a prerequisite for tackling contextual equity or the root causes of inequality.

In discourses that draw attention to contextual equity, it is predominantly civil society that advocates strategies for challenging the existing institutional arrangements that perpetuate inequalities. An example of such transformative strategies is the extent to which civil society demands greater recognition of local and indigenous rights to forests, particularly in Indonesia. State actors in Indonesia also engage with these issues, but to a much lesser extent. In Brazil, tenure and indigenous rights issues appear less often in the media, and are only raised by domestic civil society. Of the four countries examined here, Brazil is the most advanced in terms 
of recognition of indigenous rights (Larson 2011); in Indonesia, especially, this remains a very controversial issue (Indrarto et al. 2012). In Vietnam, no issues related to contextual equity were discussed in the media. The issue of local and indigenous rights is important because, in many instances, achieving substantive changes in the distribution of cost and benefits or distributive equity depends first on the recognition of these rights (Sikor 2010).

In summary, most media debates on equity and REDD+ are related to affirmative strategies and to those REDD+ safeguards that do not directly challenge the existing social and politico-economic structures that perpetuate inequalities. Domestic civil society emerges as the main policy actor advocating in the media for more transformative strategies that could tackle the root causes of inequality.

Before concluding we need to highlight some limitations of this study. First, that scant attention is given to media selection bias limits the results to the role of media representations in influencing public debate and policies. Therefore, we have to be cautious when drawing links between media and policy discourse. A comparison of discourse in policy processes and discourse in the media would shed more light on the role of the media as an independent policy actor; this is an area for further research. Second, the relatively low level of coverage in Vietnam and even more so in Peru further limits comparisons. In particular, the complete absence of state actors in the media on issues related to REDD+ and equity in Peru is more likely to be because Peru is in an early stage of REDD+ policy development than because the state is not interested (Perla Alvarez et al. 2012). In the case of Vietnam, however, there is ample evidence that actors not represented in the media also have very limited access to policy processes (Pham et al. 2012).

\section{CONCLUSION}

Discourse shapes the scope and focus of public policy agendas on equity and REDD+ according to the interests and influence of a diverse range of policy actors; the media reshapes these discourses and presents them to the public. By examining differences in the media discourse on REDD+ and equity in Indonesia, Brazil, Vietnam, and Peru, we revealed the multifaceted nature of how equity is understood and how different policy actors use different approaches to justify their calls for increased equity in the REDD+ domain.

In Indonesia and Brazil, the media play an important role in presenting REDD+ and equity-related issues to the public. In Vietnam, the print media predominantly reflects the position of government, and in Peru, the very limited coverage indicates that the print media has a minor role in these debates.

The analysis of the opinion statements of nonmedia actors suggests that the two main challenges to placing equity on the domestic REDD+ policy agenda are related to scale and to contextual equity. In most cases, dominant state actors pay little critical attention in the media to domestic equity concerns with REDD+, and most authoritative policy actors fail to engage with rights-based demands that could address some of the root causes of inequality. Overcoming these challenges will require transformational change. This will be necessary if the state is to serve the interests of a broader section of society and achieve more equitable REDD+ policy outcomes. To redress their disconnection from domestic equity issues in Indonesia, Brazil, and Peru, national state actors would need to engage more directly with the demands of civil society organizations, which serve as bridges and knowledge brokers between state and local stakeholders (Lewis and Mosse 2006). In the case of Vietnam, the absence of opinions and demands from civil society and local stakeholders seems to result in a very uncritical approach to domestic equity on the part of state actors. However, it is important that state actors engage with contextual equity issues such as the recognition and protection of local and indigenous rights because local people are likely to bear the bulk of the costs of REDD+ (Sikor 2010). Of course, improving contextual equity is also extremely difficult because, in some cases, it would require rebalancing the rights of the state itself, which controls most of the land and forest resources in these countries (White and Martin 2002). Furthermore, more attention needs to be given to procedural justice, because increased participation is often a prerequisite for tackling the root causes of inequality.

Responses to this article can be read online at: http://www.ecologyandsociety.org/issues/responses. $\mathrm{php} / 5694$

\section{Acknowledgments:}

This research is part of the policy component of the Global Comparative Study of REDD + of the Center for International Forestry Research (CIFOR) (http://www.forestsclimatechange. org/global-comparative-study-on-redd.html). We would like to thank the case study country teams that have contributed data and expertise, in particular Peter May, Daju Resosudarmo, Moira Moeliono, Thuy Thu Pham and Mary Menton. The methods applied in this study build on research undertaken by the Comparing Climate Change Policy Networks program (http://compon.org), funded by the National Science Foundation and led by Jeffrey Broadbent at the University of Minnesota. Among many members of that program, we also thank Stephan Price and Clare Saunders for sharing the Code Book for the Analysis of Media Frames in Climate Change Articles, which was adapted for the media analysis of national REDD+ policy. Funding for CIFOR's research was provided by the Norwegian Agency for Development Cooperation, the Australian Agency for 
International Development, the UK Department for International Development, the European Commission, and the US Agency for International Development.

\section{LITERATURE CITED}

Adger, N., J. Paavola, and S. Huq. 2006. Toward justice in adaptation to climate change. Pages 1-19 in W. N. Adger, J. Paavola, S. Huq, and M. J. Mace, editors. Fairness in adaptation to climate change. MIT Press, Cambridge, Massachusetts, USA.

Anand, P. 2001. Procedural fairness in economic and social choice: evidence from a survey of voters. Journal of Economic Psychology 22:247-270. http://dx.doi.org/10.1016/S0167-4870 (01)00031-9

Andsager, J. A. 2000. How interest groups attempt to shape public opinion with competing news frames. Journalism and Mass Communication Quarterly 77:577-592. http://dx.doi. org/10.1177/107769900007700308

Angelsen, A., editor. 2008. Moving ahead with REDD: issues, options and implications. Center for International Forestry Research, Bogor, Indonesia.

Babon, A., D. McIntyre, and R. Sofe. 2012. REDD+ politics in the media: a case study from Papua New Guinea. Working Paper no. 97. Center for International Forestry Research, Bogor, Indonesia.

Beymer-Farris, B. A., and T. J. Bassett. 2012. The REDD menace: resurgent protectionism in Tanzania's mangrove forests. Global Environmental Change 22:332-341. http://dx. doi.org/10.1016/j.gloenvcha.2011.11.006

Boykoff, M. T. 2008. The cultural politics of climate change discourse in UK tabloids. Political Geography 27:549-569. http://dx.doi.org/10.1016/j.polgeo.2008.05.002

Boykoff, M. T. 2009. We speak for the trees: media reporting on the environment. Annual Review of Environment and Resources 34:431-457. http://dx.doi.org/10.1146/annurev. environ.051308.084254

Brown, D., F. Seymour, and L. Peskett. 2008. How do we achieve REDD co-benefits and avoid doing harm? Pages 107-108 in A. Angelsen, editor. Moving ahead with REDD: issues, options and implications. Center for International Forestry Research, Bogor, Indonesia.

Carvalho, A. 2007. Ideological cultures and media discourses on scientific knowledge: re-reading news on climate change. Public Understanding on Science 6:223-243.

Carvalho, A., and J. Burgess. 2005. Cultural circuits of climate change in U.K. broadsheet newspapers, 1985-2003. Risk Analysis 25(6):1457-1469. http://dx.doi.org/10.1111/ j.1539-6924.2005.00692.x
Chhatre, A., S. Lakhanpal, A. M. Larson, F. Nelson, H. Ojha, and J. Rao. 2012. Social safeguards and co-benefits in REDD+: a review of the adjacent possible. Current Opinion in Environmental Sustainability 4:654-660. http://dx.doi. org/10.1016/j.cosust.2012.08.006

Corbera, E. 2012. Problematizing REDD+ as an experiment in payments for ecosystem services. Current Opinion in Environmental Sustainability 4:612-619. http://dx.doi. org/10.1016/j.cosust.2012.09.010

Corbera, E., K. Brown, and W. N. Adger. 2007. The equity and legitimacy of markets for ecosystem services. Development and Change 38:587-613. http://dx.doi. org/10.1111/j.1467-7660.2007.00425.x

Cotula, L., and J. Mayers. 2009. Tenure in REDD: start-point or afterthought? International Institute for Environment and Development, London, UK.

Cronin, T., and L. Santoso. 2010. REDD+ politics in the media: a case study from Indonesia. CIFOR Working Paper 49. Center for International Forestry Research, Bogor, Indonesia.

Di Gregorio, M., M. Brockhaus, T. Cronin, and E. Muharrom. 2012a. Politics and power in national REDD+ policy processes. Pages 69-90 in A. Angelsen, M. Brockhaus, W. D. Sunderlin, and L. Verchot, editors. Analysing REDD+: challenges and choices. Center for International Forestry Research, Bogor, Indonesia.

Di Gregorio, M., S. Price, C. Saunders, and M. Brockhaus. $2012 b$. Code book for the analysis of media frames in articles on REDD. CIFOR, Bogor, Indonesia.

Doherty, E., and H. Schroeder. 2011. Forest tenure and multilevel governance in avoiding deforestation under REDD+. Global Environmental Politics 11:66-88. http://dx.doi. org/10.1162/GLEP_a_00084

Dooley, K., T. Griffiths, F. Martone, and S. Ozinga. 2011. Smoke and mirrors: a critical assessment of the Forest Carbon Partnership Facility. FERN and Forest Peoples Programme, Moreton-in-Marsh, UK.

Duranti, A., editor. 2001. Key terms in language and culture. Blackwell, Oxford, UK.

Fairhead, J., M. Leach, and I. Scoones. 2012. Green grabbing: a new appropriation of nature? Journal of Peasant Studies 39:237-261. http://dx.doi.org/10.1080/03066150.2012.671770

Forsyth, T. 2003. Critical political ecology: the politics of environmental science. Routledge, London, UK.

Forsyth, T., and A. Walker. 2008. Forest guardians, forest destroyers: the politics of environmental knowledge in Northern Thailand. University of Washington Press, Seattle, Washington, USA. 
Fraser, N. 2009. Scales of justice: reimagining political space in a globalizing world. Columbia University Press, New York, New York, USA.

Fraser, N., and A. Honneth. 2003. Redistribution or recognition? A political-philosophical exchange. Verso, London, UK.

Freedom House. 2009. Freedom in the world: the annual survey of political rights and civil liberties. Rowman and Littlefield, Lanham, Maryland, USA.

Ghazoul, J., R. A. Butler, J. Mateo-Vega, and L. Pin Koh. 2010. REDD: a reckoning of environment and development implications. Trends in Ecology \& Evolution 25:396-402. http://dx.doi.org/10.1016/j.tree.2010.03.005

Gitlin, T. 1980. The whole world is watching: mass media in the making and unmaking of the New Left. University of California Press, Berkeley, California, USA.

Griffiths, T. 2007. Seeing "RED”? "Avoided deforestation" and the rights of indigenous peoples and local communities. Forest Peoples Programme, Moreton-in-Marsh, UK.

Hajer, M. A. 1995. The politics of environmental discourse: ecological modernization and the policy. Clarendon, Oxford, UK.

Hammond, J. L. 2004. The MST and the media: competing images of the Brazilian landless farmworkers' movement. Latin American Politics and Society 46:61-90.

Hartiningsih, M., and A. Arif. 2007. Polemik REDD Menguat - Pendapat Masyarakat Sipil Terbelah. Kompas, 8 December.

Hartono, M. D. 2007. Jual Beli Penghidupan Masyarakat. Media Indonesia, 12 November.

Heyward, M. 2007. Equity and international climate change negotiations: a matter of perspective. Climate Policy 7:518-534.

Indrarto, G. B., P. Murharjanti, J. Khatarina, I. Pulungan, F. Ivalerina, J. Rahman, M. N. Prana, I. A. P. Resosudarmo, and E. Muharrom. 2012. The context of REDD+ in Indonesia: drivers, agents and institutions. Working Paper 92. Center for International Forestry Research, Bogor, Indonesia.

Kanninen, M., D. Murdiyarso, F. Seymour, A. Angelsen, S. Wunder, and L. German, editors. 2007. Do trees grow on money? The implications of deforestation research for policies to promote REDD. Center for International Forestry Research, Bogor, Indonesia.

Kockleman, P. 2004. Stance and subjectivity. Journal of Linguistic Anthropology 14:127-150. http://dx.doi.org/10.1525/ jlin.2004.14.2.127
Koopmans, R., and P. Statham. 1999a. Political claims analysis: integrating protest event and political discourse approaches. Mobilization 4:203-221.

Koopmans, R., and P. Statham. 1999b. Challenging the liberal nation-state: postnationalism, multiculturalism, and the collective claims making of migrants and ethnic minorities in Britain and Germany. American Journal of Sociology 105:652-696. http://dx.doi.org/10.1086/210357

Larson, A. M. 2011. Forest tenure reform in the age of climate change: lessons for REDD+. Global Environmental Change 21:540-549. http://dx.doi.org/10.1016/j.gloenvcha.2010.11.008

Larson, A. M., and J. C. Ribot. 2007. The poverty of forestry policy: double standards on an uneven playing field. Sustainability Science 2:189-204. http://dx.doi.org/10.1007/ s11625-007-0030-0

Lewis, D., and D. Mosse. 2006. Development brokers and translators: the ethnography of aid and agencies. Kumarian, Bloomfield, Connecticut, USA.

Luttrell, C., L. Loft, M. F. Gebara, and D. Kweka. 2012. Who should benefit and why? Discourses on REDD+ benefit sharing. Pages 129-151 in A. Angelsen, M. Brockhaus, W. D. Sunderlin, and L. Verchot, editors. Analysing REDD+: challenges and choices. Center for International Forestry Research, Bogor, Indonesia.

Mai, P. 2010. Forest protection to combat with climate change. The People, 10 August.

May, P. H., B. Clixto, and M. F. Gebara. 2011. REDD+ politics in the media: a case study from Brazil. Working Paper 55. Center for International Forestry Research, Bogor, Indonesia.

McCarthy, J. D., C. McPhail, and J. Smith. 1996. Images of protests: dimensions of selection bias in media coverage of Washington demonstrations, 1982-1991. American Sociological Review 61:478-499. http://dx.doi.org/10.2307/2096360

McDermott, C. L., L. Coad, A. Helfgott, and H. Schroeder. 2012a. Operationalizing social safeguards in REDD+: actors, interests and ideas. Environmental Science \& Policy 21:63-72. http://dx.doi.org/10.1016/j.envsci.2012.02.007

McDermott, M., S. Mahanty, and K. Schreckenberg. $2012 b$. Examining equity: a multidimensional framework for assessing equity in payments for ecosystem services. Environmental Science \& Policy, in press. http://dx.doi. org/10.1016/j.envsci.2012.10.006

Menhut Usul Insentif REDD Direvisi - Formula Insentif Dirubah. 2007. Media Indonesia, 24 October. 
Migo, E. 2012. Citizen journalism to empower people. Satgas REDD+, Jakarta, Indonesia. [online] URL: http://www. satgasreddplus.org/en/component/k2/item/55-citizen-journalismto-empower-people

Miller, D. 1999. Principles of social justice. Harvard University Press, Cambridge, Massachusetts, USA.

Mustalahti, I., A. Bolin, E. Boyd, and J. Paavola. 2012. Can REDD+ reconcile local priorities and needs with global mitigation benefits? Lessons from Angai Forest, Tanzania. Ecology and Society 17(1): 16. http://dx.doi.org/10.5751/ ES-04498-170116

Okereke, C., and K. Dooley. 2010. Principles of justice in proposals and policy approaches to avoided deforestation: towards a post-Kyoto climate agreement. Global Environmental Change 20:82-95. http://dx.doi.org/10.1016/j. gloenvcha.2009.08.004

Países ricos devem pagar pela preservação da Amazônia. 2008. Folha de Sau Paolo. 16 June.

Perla Alvarez, J., D. Freundt Montero, E. Burga Barrantes, T. Postigo Takahashi, and M. Menton. 2012. Políticas REDD+ y los medios de comunicación: caso de estudio en el Perú. Working Paper 101. Center for International Forestry Research, Bogor, Indonesia.

Peskett, L., D. Huberman, E. Bowen-Jones, G. Edwards, and J. Brown. 2008. Making REDD work for the poor. Poverty Environment Partnership report. Overseas Development Institute, London, UK.

Peskett, L., B. Vickers, and K. Graham. 2011. Equity issues in REDD+. Overseas Development Institute, London, UK.

Pham, T. T. 2010. REDD+ politics in the media: a case study from Vietnam. Working Paper 53. Center for International Forestry Research, Bogor, Indonesia.

Pham, T. T., M. Moeliono, T. H. Nguyen, H. T. Nguyen, and T. H. Vu. 2012. The context of REDD+ in Vietnam: drivers, agents and institutions. Occasional Paper 75. Center for International Forestry Research, Bogor, Indonesia.

Phelps, J., E. L. Webb, and A. Agrawal. 2010. Does REDD+ threaten to recentralize forest governance? Science 328:312-313. http://dx.doi.org/10.1126/science.1187774

Rawls, J., and E. Kelly. 2001. Justice as fairness: a restatement. Belknap, Cambridge, Massachusetts, USA.

Sen, A. 2009. The idea of justice. Penguin, London, UK.

Sikor, T. 2010. Forest justice: towards a new agenda and practice? Journal of Integrative Environmental Science 7:245-250. http://dx.doi.org/10.1080/1943815X.2010.530878
Sikor, T., and J. Stahl, editors. 2011. Forests and people: property, governance and human rights. Earthscan, London, UK.

Stern, N. 2007. The economics of climate change: the Stern review. Cambridge University Press, Cambridge, UK.

Streck, C. 2009. Rights and REDD+: legal and regulatory considerations. Pages 151-162 in A. Angelsen, M. Brockhaus, M. Kanninen, E. Sills, W. D. Sunderlin, and S. WertzKanounnikoff editors. Realising REDD+: national strategies and policy options. Center for International Forestry Research, Bogor, Indonesia.

Sunderlin, W. D., A. M. Larson, and P. Cronkleton. 2009. Forest tenure rights and REDD+: from inertia to policy solutions. Pages 139-149 in A. Angelsen, M. Brockhaus, M. Kanninen, E. Sills, W. D. Sunderlin and S. WertzKanounnikoff editors. Realising REDD+: national strategy and policy options. Center for International Forestry Research, Bogor, Indonesia.

Suryandari, S. 2007. RI Siap Jadi Proyek Contoh REDD (Indonesia Ready for REDD Project). Media Indonesia, 5 December.

Terry, G. 2009. No climate justice without gender justice: an overview of the issues. Gender \& Development 17:5-18. http:// dx.doi.org/10.1080/13552070802696839

Trumbo, C. 1996. Constructing climate change: claims and frames in US news coverage of an environmental issue. Public Understanding on Science 5:269-283. http://dx.doi. org/10.1088/0963-6625/5/3/006

Tyler, T. R., and M. A. Belliveau. 1995. Tradeoffs in justice principles: definitions of fairness. Pages 291-314 in B. B. Bunker and J. Z. Rubin, editors. Conflict, cooperation, and justice: essays inspired by the work of Morton Deutsch. JosseyBass, San Francisco, California, USA.

United Nations Framework Convention on Climate Change (UNFCCC). 2010. Report of the Conference of the Parties on its sixteenth session, held in Cancun from 29 November to 10 December 2010: Appendix 1. UNFCCC, Cancun, Mexico.

UN-REDD. 2012. Assessing the effectiveness of training and awareness raising activities of the UN-REDD Programme in Viet Nam (2009-2011). UN-REDD Programme, Geneva, Switzerland. [online] URL: http://vietnam-redd.org/Upload/ Download/File/UN-REDD Vietnam TAR Assessment final 0844. pdf

Weiss, E. B. 1990. Our rights and obligations to future generations for the environment. American Journal of International Law 84:198-207. http://dx.doi.org/10.2307/2203020 
White, A., and A. Martin. 2002. Who owns the world's forests? Forest tenure and public forests in transition. Forest Trends and Center for International Environmental Law, Washington, D.C., USA.

Williams, L. G., and C. Davis. 2012. Getting ready with forest governance: a review of the Forest Carbon Partnership Facility readiness preparation proposals and the UN-REDD national programme documents. v 1.9. WRI Working Paper. World Resources Institute, Washington D.C., USA. [online] URL: http://pdf.wri.org/working papers/getting ready 2012-03. pdf

Young, I. M. 1990. Justice and the politics of difference. Princeton University Press, Princeton, New Jersey, USA.

Yuwono, E. 2007. Puluhan LSM Internasional Tolak 'Perdagangan' Hutan. Republika, 12 December. 